\title{
The Amino Acid Sequence of Ribonuclease $\mathbf{U}_{\mathbf{2}}$ from Ustilago sphaerogena
}

\author{
By SHOWBU SATO and TSUNEKO UCHIDA \\ Mitsubishi-Kasei Institute of Life Sciences, 11 Minamiooya, Machida-shi, Tokyo, Japan
}

(Received 3 May 1974)

\begin{abstract}
1. RNAase (ribonuclease) $U_{2}$, a purine-specific RNAase, was reduced, aminoethylated and hydrolysed with trypsin, chymotrypsin and thermolysin. On the basis of the analyses of the resulting peptides, the complete amino acid sequence of RNAase $\mathrm{U}_{2}$ was determined. 2. When the sequence was compared with the amino acid sequence of RNAase $T_{1}$ (EC 3.1.4.8), the following regions were found to be similar in the two enzymes; Tyr-Pro-His-Gln-Tyr (38-42) in RNAase $U_{2}$ and Tyr-Pro-His-Lys-Tyr (38-42) in RNAase $T_{1}$, Glu-Phe-Pro-Leu-Val (61-65) in RNAase $U_{2}$ and Glu-Trp-Pro-Ile-Leu (58-62) in RNAase $T_{1}$, Asp-Arg-Val-Ile-Tyr-Gln (83-88) in RNAase $U_{2}$ and Asp-ArgVal-Phe-Asn (76-81) in RNAase $\mathrm{T}_{1}$ and Val-Thr-His-Thr-Gly-Ala (98-103) in RNAase $\mathrm{U}_{2}$ and Ile-Thr-His-Thr-Gly-Ala (90-95) in RNAase $T_{1}$. All of the amino acid residues, histidine-40, glutamate-58, arginine-77 and histidine-92, which were found to play a crucial role in the biological activity of RNAase $T_{1}$, were included in the regions cited here. 3. Detailed evidence for the amino acid sequence of the proteins has been deposited as Supplementary Publication SUP 50041 (33 pages) at the British Library (Lending Division) (formerly the National Lending Library for Science and Technology), Boston Spa, Yorks. LS23 7BQ, U.K., from whom copies can be obtained on the terms indicated in Biochem. J. (1975), 145, 5.
\end{abstract}

RNAase* $\mathrm{U}_{2}$ from Ustilago sphaerogena is a puryloribonuclease [ribonucleate purine nucleotido2 '-transferase (cyclizing)], that is, an RNAase preferentially catalysing the cleavage of $3^{\prime}-5^{\prime}$ phosphodiester linkages of purine nucleotides in RNA. The mechanism consists of two reactions, the transfer of the phosphate group to the $2^{\prime}$-hydroxyl group of the purine nucleotides and the hydrolysis to produce 3'-phosphate of the purine nucleoside (Arima et al., 1968; Uchida et al., 1970). Earlier studies had shown that RNAase $U_{2}$ was a single-chain polypeptide consisting of 115 amino acid residues devoid of lysine and methionine and that it had half-cystine at the $N$ terminus and serine at the $C$-terminus (Uchida \& Sato, 1973a).

The present paper describes the complete amino acid sequence of RNAase $U_{2}$. It is of considerable importance to determine the amino acid sequence of RNAase $U_{2}$ in order to extend our knowledge of the relationships between the structure and function of 'cyclizing RNAases', such as RNAase $T_{1}, N_{1}, U_{2}$ and pancreatic RNAase A. Useful information about both the catalytic and specificity sites should be provided by comparing the amino acid sequence of RNAase $U_{2}$ with that of RNAase $T_{1}$ since a con-

* Abbreviations: RNAase, ribonuclease; RAE, reduced and $S$-aminoethylated. siderable amount is now known about the latter (Takahashi et al., 1970).

\section{Experimental \\ Materials}

RNAase $\mathrm{U}_{2}$ was further purified by chromatography on a column of CM-Sephadex C-50 from the partially purified RNAase $U_{2}$ obtained from Sankyo Co., Tokyo, Japan (Uchida \& Sato, 1973a). Trypsin (treated with 1-chloro-4-phenyl-3-tosylamidobutan2-one), leucine aminopeptidase and carboxypeptidase A were purchased from Worthington, Freehold, N.J., U.S.A. $\alpha$-Chymotrypsin was a product of Sigma Co., St. Louis, Mo., U.S.A. Thermolysin was obtained from Seikagaku Kogyo Co., Tokyo, Japan. Nagarse was purchased from Nagase Sangyo Ltd., Osaka, Japan. Cation-exchange resin Dowex 50 (X2) was AG-50 from Bio-Rad, Richmond, Calif., U.S.A. Phenyl isothiocyanate was redistilled under reduced pressure.

\section{Methods}

Preparation of $R A E-R N A a s e U_{2}$. The reduction and $S$-aminoethylation of RNAase $\mathrm{U}_{2}$ were performed as described by Raftery \& Cole (1966) but with dithiothreitol instead of $\beta$-mercaptoethanol. The 
final reaction mixture was dialysed against distilled water and freeze-dried.

Digestion of $R A E-R N A a s e U_{2}$ with proteolytic enzymes. (a) Trypsin. The RAE-RNAase $\mathrm{U}_{2}(55 \mathrm{mg})$ was digested with trypsin $(550 \mu \mathrm{g})$ at room temperature (about $25^{\circ} \mathrm{C}$ ) for $4 \mathrm{~h}$ in $6 \mathrm{ml}$ of $0.2 \mathrm{M}$-sodium phosphate buffer, pH7.8. (b) Chymotrypsin. The RAE-RNAase $\mathrm{U}_{2}(70 \mathrm{mg})$ was digested with $\alpha$ chymotrypsin $(400 \mu \mathrm{g})$ at room temperature for $4 \mathrm{~h}$ in $8 \mathrm{ml}$ of $0.1 \mathrm{M}-\mathrm{NH}_{4} \mathrm{HCO}_{3}$, about pH 8.0. (c) Thermolysin. The RAE-RNAase $\mathrm{U}_{2}(96 \mathrm{mg})$ was digested with thermolysin $(1.0 \mathrm{mg})$ at $37^{\circ} \mathrm{C}$ for $2 \mathrm{~h}$ in $10 \mathrm{ml}$ of $0.1 \mathrm{M}-\mathrm{NH}_{4} \mathrm{HCO}_{3}$, about pH8.0. All digestions were stopped by lowering the $\mathrm{pH}$ to 3.5 with acetic acid.

Isolation of peptides. The enzymic digests were fractionated on a column $(1.4 \mathrm{~cm} \times 400 \mathrm{~cm}$ or $1.4 \mathrm{~cm} \times 530 \mathrm{~cm}$ ) of Sephadex G-25 (fine grade) with $0.2 \mathrm{M}$-acetic acid as eluent. Peptide fractions were further purified by ion-exchange chromatography, paper electrophoresis and paper chromatography if necessary. The paper electrophoresis was carried out at $65 \mathrm{~V} / \mathrm{cm}$ on no. 50 filter paper (Toyo Kagaku Co., Tokyo, Japan) in a tank containing Isopar H (Esso-Standard Product, Tokyo, Japan) as coolant. Two buffer systems with different $\mathrm{pH}$ values were used; pyridine-acetic acid-water (1:10:289, by vol.) for $\mathrm{pH} 3.7$ and (25:1:225, by vol.) for $\mathrm{pH} 6.5$. The paper chromatography was done on the above filter paper with butan-1-ol-acetic acid-water $(4: 1: 2$, by vol.) at room temperature for $24 \mathrm{~h}$ by the ascending method. The paper was air-dried and the parts carrying peptides were cut out with the aid of guide strips, which were stained by spraying with ninhydrin or tolidine reagent. The peptides were eluted from the paper with $0.2 \mathrm{M}$-acetic acid.

Enzymic digestion of peptides. Some of the peptides obtained from the proteinase digests of RAE-RNAase $\mathrm{U}_{2}$ were further digested to smaller fragments with trypsin, chymotrypsin, thermolysin or Nagarse. Enzymic digestion was performed in $0.1 \mathrm{M}-\mathrm{NH}_{4} \mathrm{HCO}_{3}$ at $37^{\circ} \mathrm{C}$ for $16 \mathrm{~h}$. The enzyme/substrate ratio was $1: 20-30(w / w)$.

Sequence analysis. (a) Dinitrophenylation. The procedure described by Fraenkel-Conrat et al. (1955) was used. Dinitrophenyl amino acids were identified by t.l.c. on an aluminium sheet of silica gel $F_{254}$ or polyamide II $F_{254}$ (E. Merck Co., Darmstadt, Germany) (Niederweiser, 1972). (b) Hydrazinolysis. The procedure described by Schroeder (1972) was used to liberate the $C$-terminal amino acid, which was identified and determined quantitatively on an amino acid analyser. (c) Edman degradation. The subtractive procedure described by Konigsberg (1967) was used. In some cases, the phenylthiohydantoins of amino acids were released from peptides by direct Edman degradation as described by Blombäck et al. (1966) and identified by t.l.c. on an aluminium sheet of silica gel $\mathrm{F}_{254}$ (E. Merck Co.) (Niederweiser, 1972). (d) Hydrolysis of peptides with leucine aminopeptidase or carboxypeptidase A. Peptides (10-50 nmol) were hydrolysed with $10-50 \mu \mathrm{g}$ of the enzyme in $0.2 \mathrm{ml}$ of $0.1 \mathrm{M}$-sodium phosphate buffer, $\mathrm{pH}$ 8.0. The hydrolysates were directly subjected to amino acid analysis.

Amino acid analysis. Peptide was hydrolysed with $0.5 \mathrm{ml}$ of glass-distilled constant-boiling $\mathrm{HCl}$ in a sealed evacuated tube at $110^{\circ} \mathrm{C}$ for $22 \mathrm{~h}$. The $\mathrm{HCl}$ was removed at $40^{\circ} \mathrm{C}$ under reduced pressure. Chromatography was performed by the method of Spackman et al. (1958) with an automatic amino acid analyser JLC-6AH (JEOL Ltd., Tokyo, Japan). The yields of peptides were based on the results of amino acid analysis. The values for serine, threonine, tyrosine and aminoethylcysteine were not corrected for degradation during hydrolysis. Tryptophan was detected by Ehrlich reaction on papers.

Determination of amides of aspartic acid and glutamic acid. Amides were assigned on the basis of electrophoretic mobility of the parent peptides at pH6.5 by the method of Offord (1966) or by chromatographic determination of glutamine and asparagine in the digests of peptides with leucine aminopeptidase or carboxypeptidase A on an amino acid analyser.

Nomenclature. Peptides isolated and purified from tryptic, chymotryptic, thermolytic and Nagarse hydrolysates of RAE-RNAase $\mathrm{U}_{2}$ or its fragments are designated $\mathrm{T}, \mathrm{C}, \mathrm{L}$ and $\mathrm{N}$ respectively. They are followed by an arabic number indicating the order of the peptide alignment from the $\mathrm{N}$-terminus in the protein molecule.

\section{Results}

RAE-RNAase $U_{2}$ was digested with trypsin, chymotrypsin or thermolysin. Digests were fractionated by gel filtration followed by high-voltage paper electrophoresis. For some fractions obtained by gel filtration of tryptic or thermolytic digests, column chromatography on cation-exchange resin was used. Paper chromatography was used for further purification if necessary.

The amino acid compositions and purities of peptides were determined by quantitative amino acid analysis. The amount of aminoethylcysteine, threonine, serine and tyrosine in some peptides was found to be lower than expected from sequence analysis of the peptides, probably because of degradation during acid hydrolysis. The total number of amino acid residues found in the protein by analysis of the peptídes was 113, which was one aspartic acid and one proline less than that found by whole protein analysis (Uchida \& Sato, 1973a).

The yield of purified peptides was in the range $10-60 \%$ for tryptic or chymotryptic peptides and in the range $3-30 \%$ for thermolytic peptides. 


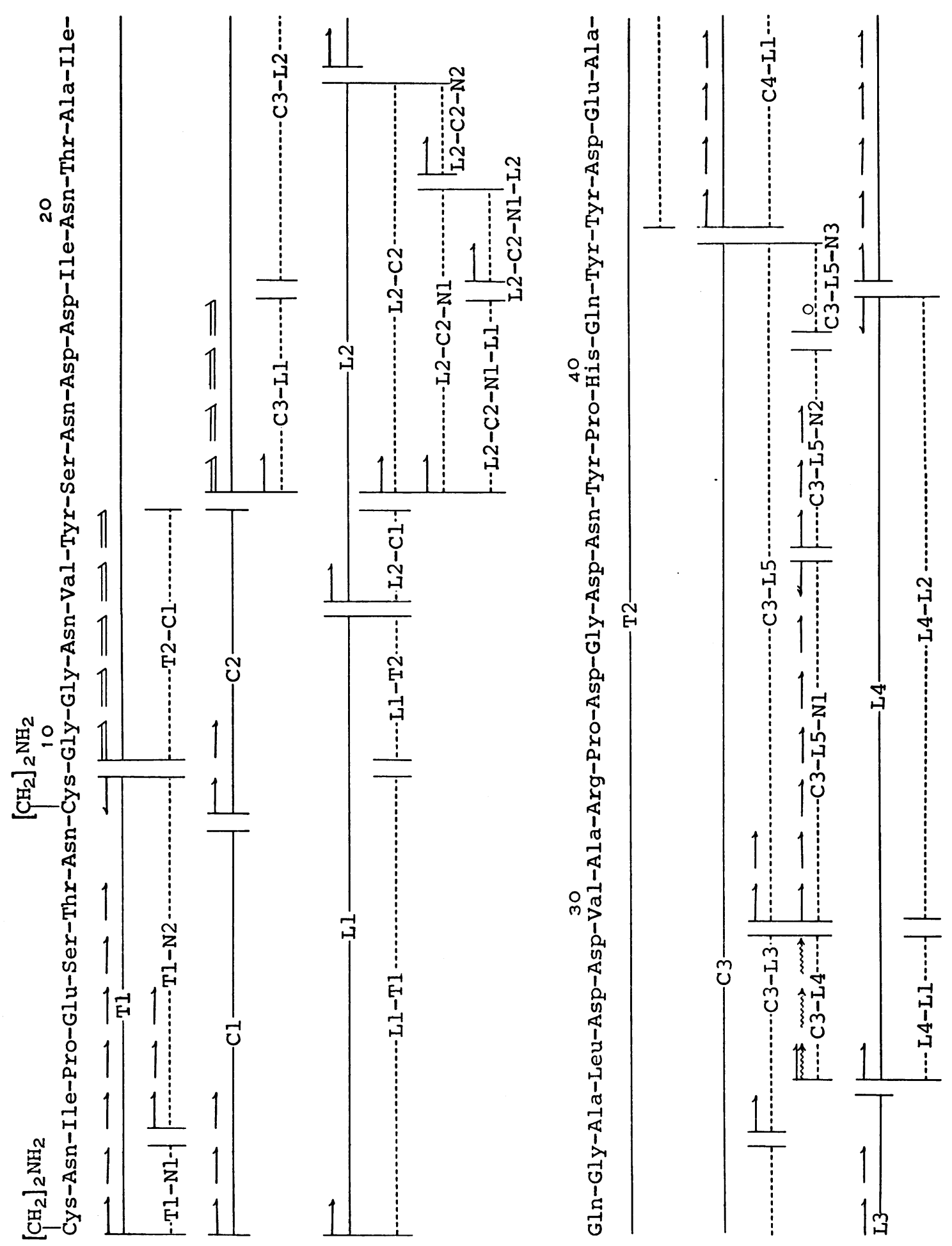

Vol. 145 


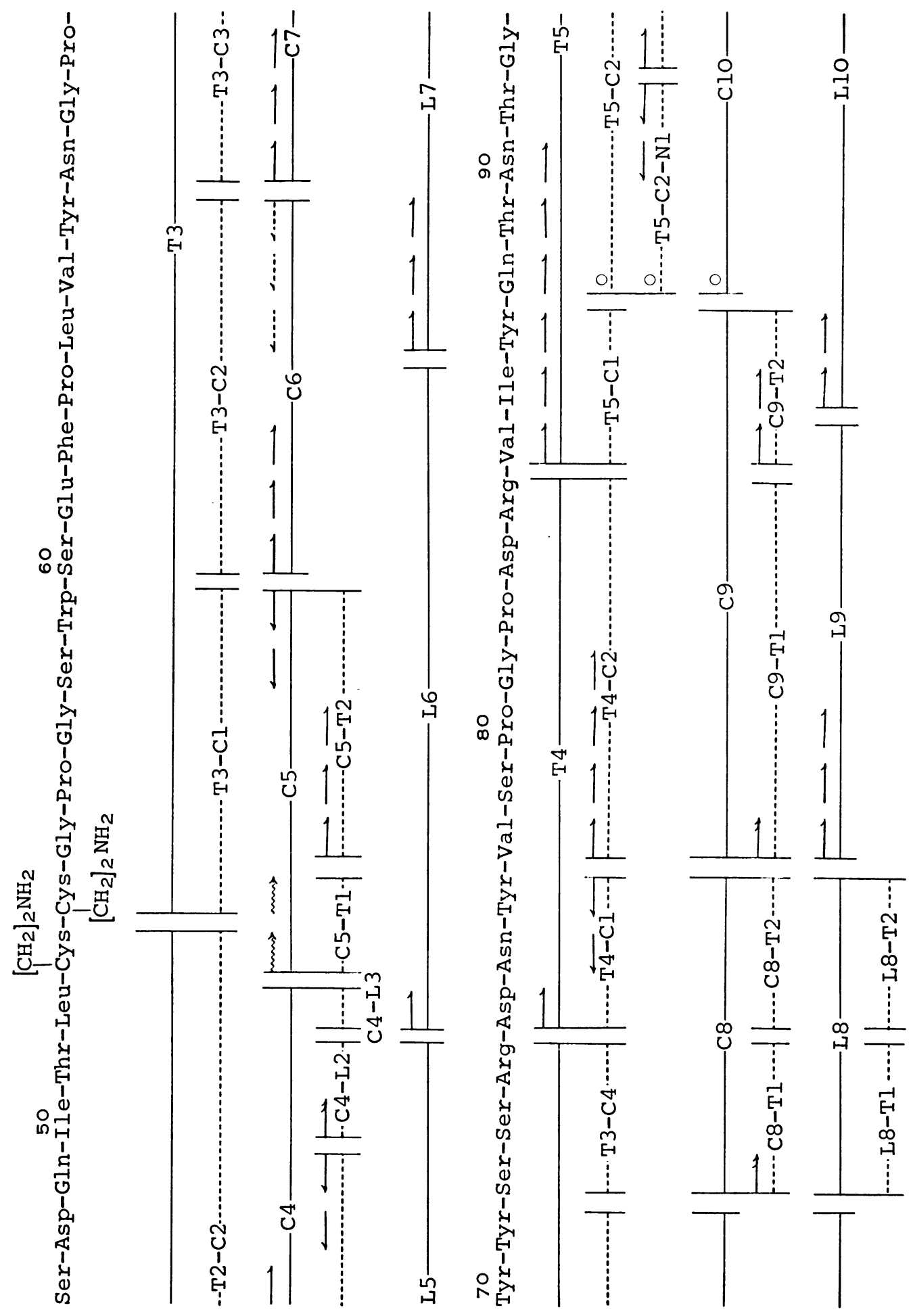




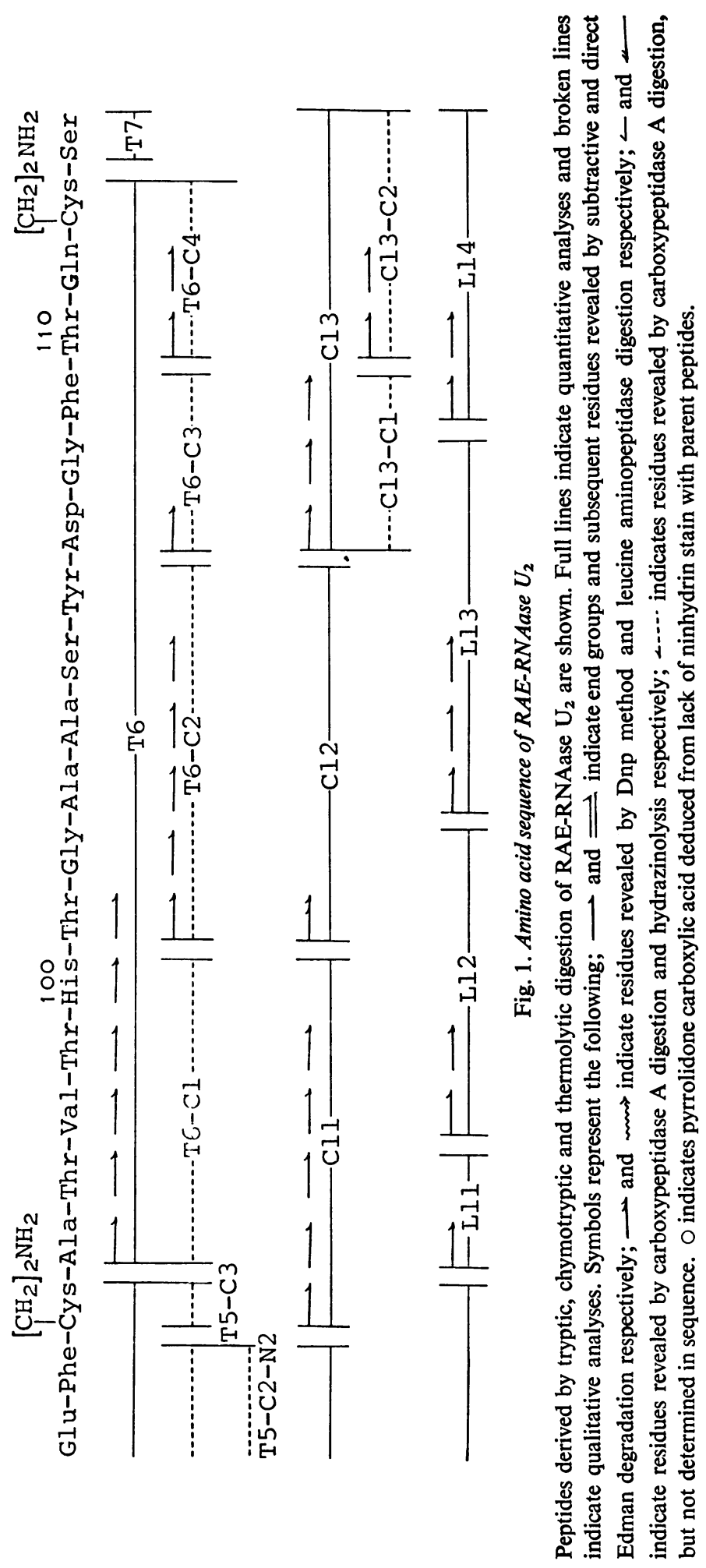


$N$-Terminal residues were determined by the Dnp method or partial sequences of the purified peptides by direct or subtractive Edman degradation. $C$ Terminal regions were determined by carboxypeptidase $\mathbf{A}$ or hydrazinolysis and in some cases were deduced from the substrate specificity of the proteolytic enzymes. Larger peptides were degraded by further proteolysis and the resulting small peptides were analysed.

Amide residues were located by examining the electrophoretic mobility at pH6.5 of simple peptides or by amino acid analysis of carboxypeptidase $A$ or leucine aminopeptidase digests of the peptides. In a difficult case, the remaining peptide obtained by Edman degradation was digested with carboxypeptidase A.

From the partial-sequence data obtained with the tryptic, chymotryptic and thermolytic peptides of RAE-RNAase $\mathrm{U}_{2}$ the construction of the complete amino acid sequence of RAE-RNAase $\mathrm{U}_{2}$ was possible. The evidence for the amino acid sequence is summarized in Fig. 1 . Since the $N$-terminal amino acid of oxidized RNAase $U_{2}$ was cysteic acid (Uchida \& Sato, 1973a), the thermolytic peptide L1 is the $N$-terminal peptide of RAE-RNAase $\mathrm{U}_{2}$. One of the tryptic peptides of peptide L1 (L1-T1) was the same as one of the tryptic peptides of RAE-RNAase $U_{2}$, peptide $T 1$. Therefore the tryptic peptide $T 1$ and the chymotryptic peptide $\mathrm{Cl}$ are the $N$-terminal peptide. The thermolytic peptide L3 was located between peptides $\mathrm{L} 2$ and $\mathrm{L} 4$ because the overlapping peptide between peptides L3 and L4, Ala-Leu-AspAsp, was isolated from the thermolytic digest of peptide C3. Peptide L6 gave the necessary overlap, which placed peptide T3 after T2 in tryptic peptides and sequenced peptides C4-C5-C6 in chymotryptic peptides. The overlapping of the chymotryptic peptides $\mathrm{C7}$ and $\mathrm{C} 8$ and of the thermolytic peptides L7 and L8 were made by the tryptic peptide T3 containing the sequence, Ser-Ser-Arg, which was the $\mathrm{N}$-terminal sequence of both peptides C8 and L8. Peptide T7 is the $C$-terminus because the $C$-terminal serine has been shown by the analysis of the oxidized protein (Uchida \& Sato, 1973a) and because it was a single peptide which contained neither arginine nor aminoethylcysteine. Peptide $\mathrm{C} 13$ and L14 provided the overlap between peptides $\mathrm{T} 6$ and $\mathrm{T} 7$.

\section{Discussion}

From analysis of the whole protein, it has been reported that the number of amino acid residues in RNAase $U_{2}$ is 115 , which is one aspartic acid and one proline more than the present data obtained by peptide analysis (Uchida \& Sato, 1973a). Analysis of the peptides obtained by digestion of the protein with three kinds of proteinase has shown that there is no place in the sequence for an extra aspartic acid and an extra proline. The amount of aspartic acid and proline in the earlier studies must have been overestimated, probably because of the high content of aspartic acid in the protein (about $18 \%$ of the total residues) and the low colour yield of proline.

It is noticeable that there are some similar sequences in RNAase $U_{2}$ and RNAase $T_{1}$, as indicated by the boxes in Fig. 2. Two cysteine residues near the $N$-terminus and one residue in the $C$-terminal part of RNAase $U_{2}$ are located at about the same position as in RNAase $T_{1}$. The $C$-terminal serine in RNAase $U_{2}$ is analogous to the threonine in RNAase $T_{1}$. The sequence of five residues containing histidine- 40 in RNAase $U_{2}$ is the same as that containing histidine- 40 in RNAase $T_{1}$ except for one residue, namely glutamine in RNAase $U_{2}$ is replaced by lysine in RNAase $T_{1}$. The same is true of the sequence through the six residues containing histidine-100 in RNAase $U_{2}$ and that containing histidine- 92 in RNAase $T_{1}$. In this case, valine in RNAase $U_{2}$ is replaced by isoleucine in RNAase $T_{1}$. Further, the region (83-88) containing one of the arginine residues (84) in RNAase $U_{2}$ is similar to the surroundings of the single arginine residue (77) in RNAase $T_{1}$, with the replacement of the sequence Ile-Tyr-Gln in RNAase $U_{2}$ by the analogous sequence Val-Phe-Asn in RNAase $T_{1}$. Earlier studies (Uchida \& Sato, 1973b) showed that a carboxymethylated heptapeptide containing glutamic acid was isolated from the chymotryptic digest of RNAase $\mathrm{U}_{2}$ inactivated with monoiodoacetic acid. The glutamine residue of this heptapeptide is positioned at the 61st residue and is followed by a hydrophobic cluster, Phe-Pro-Leu-Val; the crucial glutamine residue (58) in RNAase $T_{1}$ (Takahashi et al., 1967) is followed by Trp-Pro-Ile-Leu (59-62). In addition, this glutamine residue in RNAase $\mathrm{U}_{2}$ is located near the single tryptophan residue as shown in RNAase $T_{1}$. It is noteworthy that the regions containing the two histidine residues, the one arginine residue and the crucial glutamine residue in both enzymes are analogous to each other whereas there is no similarity in the other regions, which account for most of the residues. RNAase $U_{2}$ is inactivated by photo-oxidative destruction of histidines, as is RNAase $T_{1}$ (Uchida \& Sato, 1973b) and modification with phenylglyoxal inactivates both RNAase $\mathrm{U}_{2}$ (S. Sato, M. Sato \& T. Uchida, unpublished work) and RNAase $T_{1}$ (Takahashi, 1970). In addition to the results obtained by carboxymethylation, the results from these chemical modification studies suggest that analogous regions in the two enzymes form the active site. Some or all of them probably function in a similar manner in the catalytic site of both enzymes. However, further chemical modification studies that actually distinguish the specificity site are necessary before it can be said whether or not the specificity site is formed from some region other 


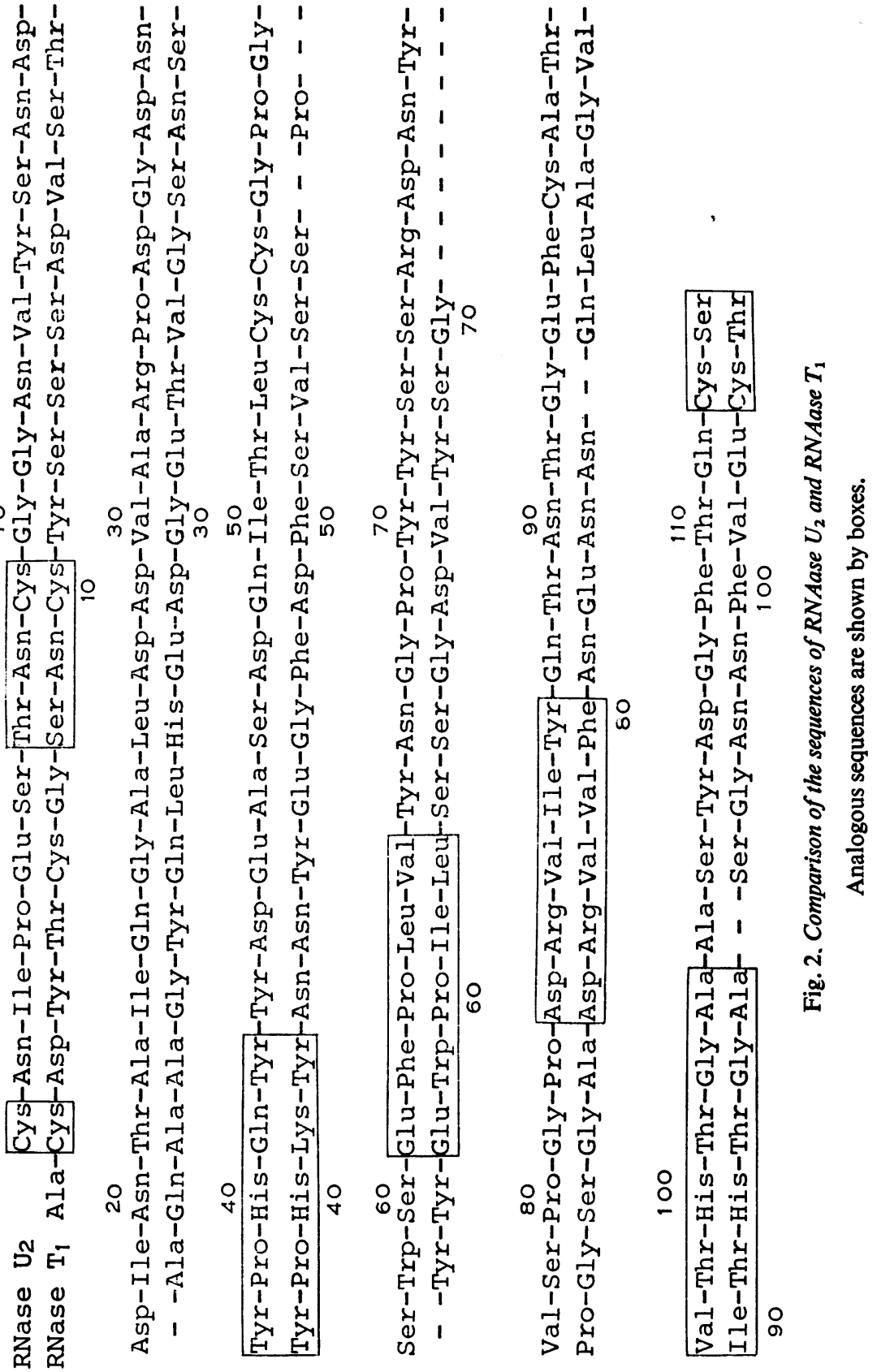


than the analogous ones or if some replacements in the analogous regions can be responsible for the different base specificities of the enzymes.

From the point of view of molecular evolution, both enzymes might originate from the same ancestor, and functionally important sequences might remain unchanged during mutation.

We thank Dr. F. Egami for his continued encouragement and helpful advice throughout this study.

\section{References}

Arima, T., Uchida, T. \& Egami, F. (1968) Biochem.J. 106, 609-613

Blombäck, B., Blombäck, M., Edman, P. \& Hessel, B. (1966) Biochim. Biophys. Acta 115, 371-396

Fraenkel-Conrat, H., Harris, J. I. \& Levey, A. L. (1955) Methods Biochem. Anal. 2, 359-425
Konigsberg, W. (1967) Methods Enzymol. 11, 461-469

Niederweiser, A. (1972) Methods Enzymol. 25, 60-99

Offord, R. E. (1966) Nature (London) 211, 591-593

Raftery, M. A. \& Cole, R. D. (1966) J. Biol. Chem. 241, 3457-3461

Schroeder, W. A. (1972) Methods Enzymol. 25, 138-143

Spackman, D. H., Stein, W. H. \& Moore, S. (1958) Anal. Chem. 30, 1190-1206

Takahashi, K. (1970) J. Biochem. (Tokyo) 68, 659-664

Takahashi, K., Stein, W. H. \& Moore, S. (1967) J. Biol. Chem. 242, 4682-4690

Takahashi, K., Uchida, T. \& Egami, F. (1970) Advan. Biophys. 1, 53-98

Uchida, T. \& Sato, S. (1973a) Abstr. Int. Congr. Biochem. 9th p. 107, 2q8

Uchida, T. \& Sato, S. (1973b) in Ribosomes and RNA Metabolism (Zelinka, J. \& Balan, J., eds.), pp. 453-472, Publishing House of the Slovak Academy of Sciences, Bratislava

Uchida, T., Arima, T. \& Egami, F. (1970) J. Biochem. (Tokyo) 67, 91-102 